\title{
Evaluation of the Serum Visfatin and Adiponectin Levels Related with the Activity of Juvenile Idiopathic Arthritis
}

\section{Juvenil İdiyopatik Artrit Aktivitesi ile Ilişkili Serum Visfatin ve Adiponektin Düzeylerinin Değerlendirilmesi}

(1) Oktay Çalışkan1, (1) Zeynep Banu Güngör1, (1) Özlem Balcı Ekmekçi1, (10 Hakan Ekmekçi1, (1) Kenan Barut2, (1) Sezgin Şahin22, (1) Amra Adroviç Yıldız2, (1) Şeyma Dümür1, (1) Özgür Kasapçopur2, (1) Mine Kucur

${ }^{1}$ ìstanbul University-Cerrahpaşa, Cerrahpaşa Faculty of Medicine, Department of Medical Biochemistry, İstanbul, Turkey

${ }^{2}$ istanbul University-Cerrahpaşa, Cerrahpaşa Faculty of Medicine, Department of Pediatric Rheumatology, İstanbul, Turkey

Cite this article as: Çalışkan O, Güngör ZB, Balcı Ekmekçi Ö, Ekmekçi H, Barut K, Şahin S, Adroviç Yıldız A, Dümür Ş, Kasapçopur Ö, Kucur M. Evaluation of the Serum Visfatin and Adiponectin Levels Related with the Activity of Juvenile Idiopathic Arthritis. J Acad Res Med 2021;11(2):120-5

\begin{abstract}
Objective: This study aimed to investigate the possible relationship of serum adiponectin and visfatin levels that are derived from the adipose tissue in patients with juvenile idiopathic arthritis (JIA), in accordance with the routinely used biochemical parameters, to evaluate the management of therapy and assessment of disease activity.

Methods: According to the Wallace criteria, the study population was divided into active, remission and control groups. Serum adiponectin and visfatin levels were measured by the enzyme-linked immunosorbent assay method. Complete blood count, erythrocyte sedimentation rate (ESR) and C-reactive protein (CRP) were routinely measured. Neutrophil/lymphocyte ratio (NLR) was calculated.

Results: Significant differences were found in serum visfatin levels between the active and the control groups $(p<0.05)$ and in serum adiponectin levels between the active and remission groups $(p<0.05)$. Significant differences were also observed in routinely used parameters, namely; ESR, CRP and platelet count $(p<0.05)$, among the active, remission and control groups, whereas the leukocyte and neutrophil counts together with the percentage of neutrophils, lymphocytes and NLR established significant differences only between the active and control groups $(p<0.05)$.

Conclusion: The results suggest that serum visfatin levels may be useful to indicate disease activity in accordance with the correlation between ESR and CRP in patients with JIA. Unlike visfatin, serum adiponectin levels may be utilised in the management of treatment rather than as a diagnostic parameter on the onset of JIA. Although this study included a small sample of patients with JIA, it highlights the potential of the two adipose tissuederived parameters as new biochemical parameters in $\mathrm{JIA}$, both in the assessment of disease activity and the management of treatment, which are essential to improve the life quality of these patients.
\end{abstract}

Keywords: Adipocytokine, adiponectin, inflammation, juvenile idiopathic arthritis, visfatin

\section{Öz}

Amaç: Amacımız, adipoz dokudan salgılanan adiponektin ve visfatin düzeylerinin juvenil idiyopatik artrit (JiA) aktivitesi ile olası ilişkisini rutin kullanılan biyokimyasal parametrelerle karşılaştırarak değerlendirmek ve hastalık aktivitesi ile tedavinin izlenmesinde bu iki parametrenin rolünü araştırmaktır.

Yöntemler: Wallace kriterlerine göre; çalışma grubu aktif, remisyon ve kontrol gruplarından oluşmaktadır. Serum adiponektin ve visfatin seviyeleri enzime bağlı immunosorbent test yöntemi ile analiz edilmiştir. Tam kan sayımı, eritrosit sedimantasyon hızı (ESH) ve C-reaktif protein (CRP) rutin olarak ölçüldü. Nötrofil/lenfosit oranı (NLO) hesaplandı.

Bulgular: Aktif ve kontrol grupları arasında serum visfatin düzeylerinde istatistiksel olarak anlamlı farklılık bulunurken $(p<0,05)$; serum adiponektin düzeyleri açısından aktif ve remisyon grupları arasında anlamlı farklılık bulundu $(p<0,05)$. Rutin olarak ölçülen laboratuvar parametrelerinde de anlamlı farklılıklar saptandı; aktif, remisyon ve kontrol grupları arasında ESH, CRP ve trombosit sayıları anlamlı $(p<0,05)$ iken; lökosit ve nötrofil sayıları ile nötrofil, lenfosit yüzdeleri ve NLO değerlerinde ise sadece aktif ve kontrol grupları arasında anlamlı farklar $(p<0,05)$ bulundu.

ORCID IDs of the authors: O.Ç. 0000-0002-1522-9823; Z.B.G. 0000-0002-0649-844X; Ö.B.E. 0000-0001-7432-9915; H.E. 0000-0002-5605-2980; K.B. 0000-0001-8459-2872; S.Ş. 0000-0002-5365-3457; A.A.Y. 0000-0002-2400-6955; Ş.D. 0000-0001-8893-2926; Ö.K. 0000-0002-1125-7720; M.K. 0000-0002-6579-1996.

Corresponding Author/Sorumlu Yazar: Mine Kucur, E-mail: mkucur@hotmail.com

Presented in: Congress \& LAB. Expo 2018 with International Participation and $1^{\text {st }}$ Hereditary Metabolic Diseases Symposium (01-04 October 2018, Antalya) P4-02.
Received Date/Geliş Tarihi: 15.02.2021 Accepted Date/Kabul Tarihi: 26.03.2021

(C) Copyright 2021 by University of Health Sciences Turkey, Gaziosmanpaşa Training and Research Hospital. Available on-line at www.jarem.org

(CTelif Hakkı 2021 Sağlık Bilimleri Üniversitesi, Gaziosmanpaşa Eğitim ve Araştıma Hastanesi. Makale metnine www.jarem.org web sayfasından ulaşılabilir. 
Sonuç: JiA hastalarında serum visfatin düzeylerinin, ESH ve CRP değerleri ile korelasyonu göz önüne alındığında bu iki parametrenin hastalığın aktivitesini değerlendirmede yararlı olabileceğini düşünmekteyiz. Visfatinin aksine; serum adiponektin düzeyleri, JiA'nın başlangııında hastalığın aktivitesi açısından tanısal parametre yerine tedavinin yararlılı̆ının izlenmesinde kullanılabilir. Bu çalışmada yer alan JiA'lı olgu sayısı relatif olarak az olmasına rağmen yine de bu iki yeni parametrenin hastalığın aktivitesinin değerlendirilmesinde ve tedavinin etkinliğinin izlenmesinde özellikle yaşam kalitelerinin iyileştirilmesi yönünde katkıda bulunacağına inanıyoruz.

Anahtar kelimeler: Adipositokin, adiponektin, enflamasyon, juvenil idiyopatik artrit, visfatin

\section{INTRODUCTION}

Juvenile idiopathic arthritis (JIA), formerly known as juvenile rheumatoid arthritis, is characterised by idiopathic permanent arthritis lasting at least 6 weeks and onset before age 16 years after the exclusion of other inflammatory diseases, such as reactive arthritis, inflammatory bowel disease and systemic lupus erythematosus. JIA progresses to childhood arthritis in which prolonged synovial inflammation may result in growth impairment, joint destruction, osteoporosis and chronic pain as long-term consequences (1).

Wallace et al. (2) suggested specific criteria for determining the disease activity of children with JIA. To be considered having inactive disease, patients should not have active arthritic joints, fever, rash, serositis, splenomegaly or generalised lymphadenopathy and active uveitis, and normal values of both erythrocyte sedimentation rate (ESR) and C-reactive protein (CRP). Clinical remission with medication is considered inactive for a period minimum of six consecutive months under medication, whereas clinical remission without medication is proposed as 12 consecutive months without anti-arthritis and anti-uveitis medications.

JIA is an inflammatory disease accompanied with innate and adaptive immune system disorders. A dysregulation of the alternative secretory pathway leads to loss of monocytes, macrophages and neutrophils with aberrant activation of phagocytes and plays a role in the release of interleukin (IL)- 1 , IL-6, IL-8 and proinflammatory S-100 proteins. Eventually, this contributes to multisystem inflammation of JIA $(3,4)$.

Recent studies involving laboratory parameters aimed to determine inflammation, clarify the pathogenesis of the disease and monitor side effects of treatment. Complete blood count (CBC) rheumatoid factor as well as other inflammatory markers, such as ESR and CRP, are commonly used laboratory parameters in the management of JIA. The treatment goal is disease remission. ESR and CRP, which are acute-phase proteins, are used in the diagnosis and monitoring of both active and remission periods $(2,3,5,6)$.

Many inflammatory mediators including cytokines [such as IL-1, IL-6, IL-8 and tumour necrosis factor-alpha (TNF- $\alpha$ )] and adipokines (such as leptin, adiponectin, resistin and visfatin) are released from the adipose tissue $(4,7)$. Adipokines participate in the pathogenesis of various pathologies, mainly inflammation, obesity, insulin resistance, metabolic syndrome and autoimmune diseases such as rheumatoid arthritis $(5,6,8,9)$.
Research studies have recently shown that both adiponectin and visfatin may have critical roles in the pathogenesis of $\mathrm{JIA}$, but this has not yet been clarified. Although the aetiology of JIA is unknown, the immunological predisposition is emphasised and JIA is considered an antigen-dependent T-lymphocyte-mediated autoimmune disease $(7,10)$.

Recent studies have indicated that extracellular matrix degradation and joint destruction induced both the infiltration of adiponectin and migration of monocytes towards the synovium, acting as a proinflammatory mediator in joint diseases $(8,11)$.

Conversely, visfatin enhances the release of CD54 (ICAM), CD40 and CD80 molecules that are effective in activating T-cells and $\mathrm{CD} 14+$, and CD19+ chemotaxic molecules for monocytes and $\mathrm{B}$ cells $(9,12)$. Additionally, studies have shown that the expression of ICAM-1 and VCAM- 1 as a response to reactive oxygen species production is enhanced by visfatin $(10,13)$.

In this study, serum adiponectin and visfatin levels were measured in both active and remission periods of a group of patients with JIA in comparison with a control group. Thus, this study aimed to investigate the predictive roles of these two adipose tissue-derived parameters in monitoring disease activity and management of the treatment of JIA.

\section{METHODS}

A total of 87 patients with JIA undergoing follow-up in Cerrahpaşa Medical Faculty Department of Pediatric Rheumatology, İstanbul University Cerrahpaşa, and 50 control subjects were enrolled in this study.

Patients with JIA were diagnosed according to 2001 International League of Associations For Rheumatology classification criteria $(11,14)$. Fifty healthy children whose age and sex were similar to the patient groups, did not receive any medication and had no infection and other any systemic diseases (such as malignancy, chronic inflammatory disease, endocrine disorder, malabsorption, liver disease and obesity) were included in this study. Patients were categorised according to the validated Wallace criteria for patients with JIA dependent of the active or remission period $(12,15)$.

Written informed consent was obtained from all patients. The study protocol was approved by Ethics Committee of İstanbul University-Cerrahpaşa, Cerrahpaşa Faculty of Medicine (approval number: 02-107694, approval date: 07.04.2015). 


\section{Sample Collection}

In this study, $5 \mathrm{~mL}$ of blood was collected into gel tubes without anticoagulants for adiponectin and visfatin analysis and left for 30 $\mathrm{min}$ for coagulation. After centrifugation at 4,000 rpm for $7 \mathrm{~min}$, serum was collected into separate tubes and stored at $-20^{\circ} \mathrm{C}$ until analysis. Serum adiponectin and visfatin levels were measured by enzyme-linked immunoabsorbent assay kits (eBioscience Inc. San Diego, CA 92121 United States BMS2032/2 and SunRed, 201-120026, respectively) according to the manufacturer's instructions. CBC (Beckman Coulter LH780), ESR (Therma NE Linear) and CRP (Roche Cobas C 501) were also analysed. Neutrophil/lymphocyte ratio (NLR) was calculated by dividing neutrophil count by lymphocyte count in CBC.

\section{Statistical Analysis}

SPSS Statistics for Windows v. 20 software (IBM Corp., Armonk, NY, USA) was used for statistical analysis of the study variables. Analysis of variance test was performed to analyse differences among variables between the subgroups. Student's t-test (homogeneous groups) was performed for binary comparisons. The Pearson test was used to analyse correlation. A value of $p<0.05$ was considered significant. Numerical values obtained were expressed as mean \pm standard deviation or standard error of the mean.

\section{RESULTS}

The population of this study consisted of 87 children $(n=37,42.5 \%$ male; $n=50,57.5 \%$ female) with JIA and 50 healthy controls ( $n=27$, $54 \%$ male; $n=23,46 \%$ female).

\section{Demographic Data}

The gender and age distribution of the study population is shown in Table 1. No significant difference was found between the patient group and the control group in terms of gender and age ( $p>0.05)$.

Patients with JIA were divided into active and remission groups. In the last 6 months, patients with no active arthritis or with no rash and clinical inactive disease were included in the remission group.

\section{Routine Laboratory Parameters}

Significant differences were found in routinely used parameters, including ESR, CRP and platelet count $(p<0.05)$ among the active, remission and control groups, whereas significant differences were observed only between the active and control groups in terms of the leukocyte and neutrophil counts, along with the percentage of neutrophils, lymphocytes and NLR $(p<0.05)$. Routine laboratory parameters of the study groups are detailed in Table 2 .

Table 1. Gender and age distribution in the active, remission and control groups

\begin{tabular}{|l|l|l|l|l|}
\hline & $\begin{array}{l}\text { Active } \\
\mathbf{n = 5 4}\end{array}$ & $\begin{array}{l}\text { Remission } \\
\mathbf{n = 3 3}\end{array}$ & $\begin{array}{l}\text { Control } \\
\mathbf{n = 5 0}\end{array}$ & p value \\
\hline Male & $25(46.3 \%)$ & $12(36.4 \%)$ & $27(54 \%)$ & 0.992 \\
\hline Female & $29(53.7 \%)$ & $21(63.6 \%)$ & $23(46 \%)$ & 0.992 \\
\hline Age (year) & $9.4 \pm 3.9$ & $9.1 \pm 4.1$ & $9.3 \pm 4.6$ & 0.972 \\
\hline
\end{tabular}

\section{Serum Adiponectin and Visfatin Levels}

Serum adiponectin levels were decreased in both the remission group and control group when compared with the active group (Figure 1). However, a significant decline was observed only between the active and remission groups $(p<0.05)$. Markedly low adiponectin values are observed in the remission period than in the control group. Although serum visfatin levels were also lower in both the remission and control groups than in the active group, significant difference was found only between the active and control groups $(p<0.05)$ (Figure 2). A subsequent decline was observed in visfatin values among the study groups. These results are illustrated in Table 3. A positive correlation was found between visfatin and CRP ( $r=0.459, p=0.007)$ and ESR values $(r=0.409, p=0.018)$ (Figure 3).

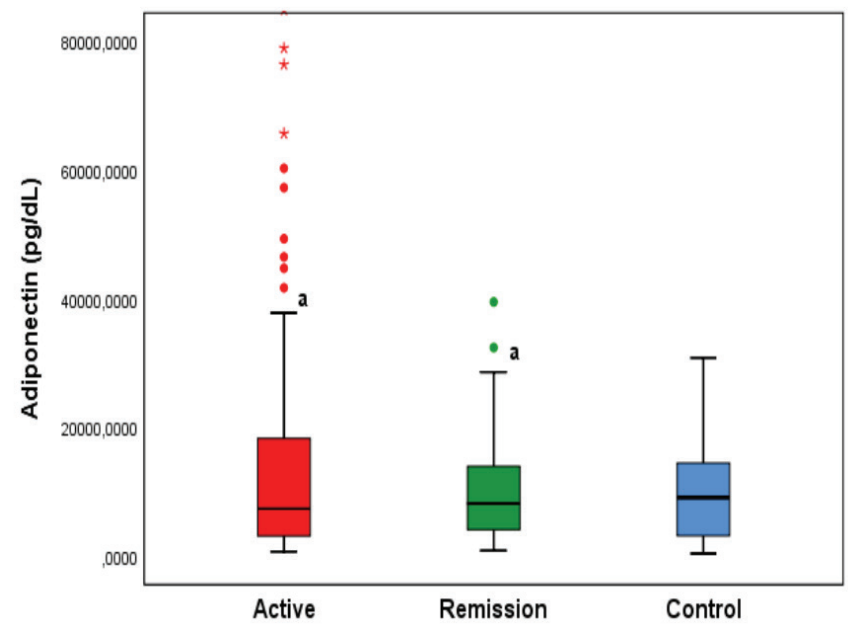

Figure 1. Serum adiponectin ( $\mathrm{pg} / \mathrm{dL}$ ) levels in the active, remission and control groups

a: comparison of active group and remission group $(p<0.05)$

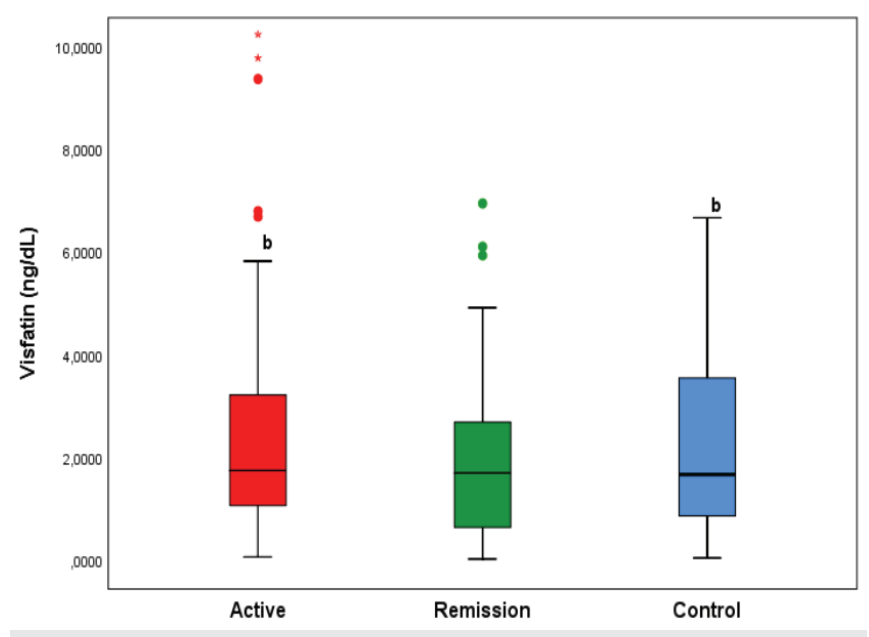

Figure 2. Serum visfatin (ng/dL) levels in the active, remission and control groups

b: comparison of active group and control group $(p<0.05)$ 


\section{Table 2. Routine laboratory parameters of the study groups}

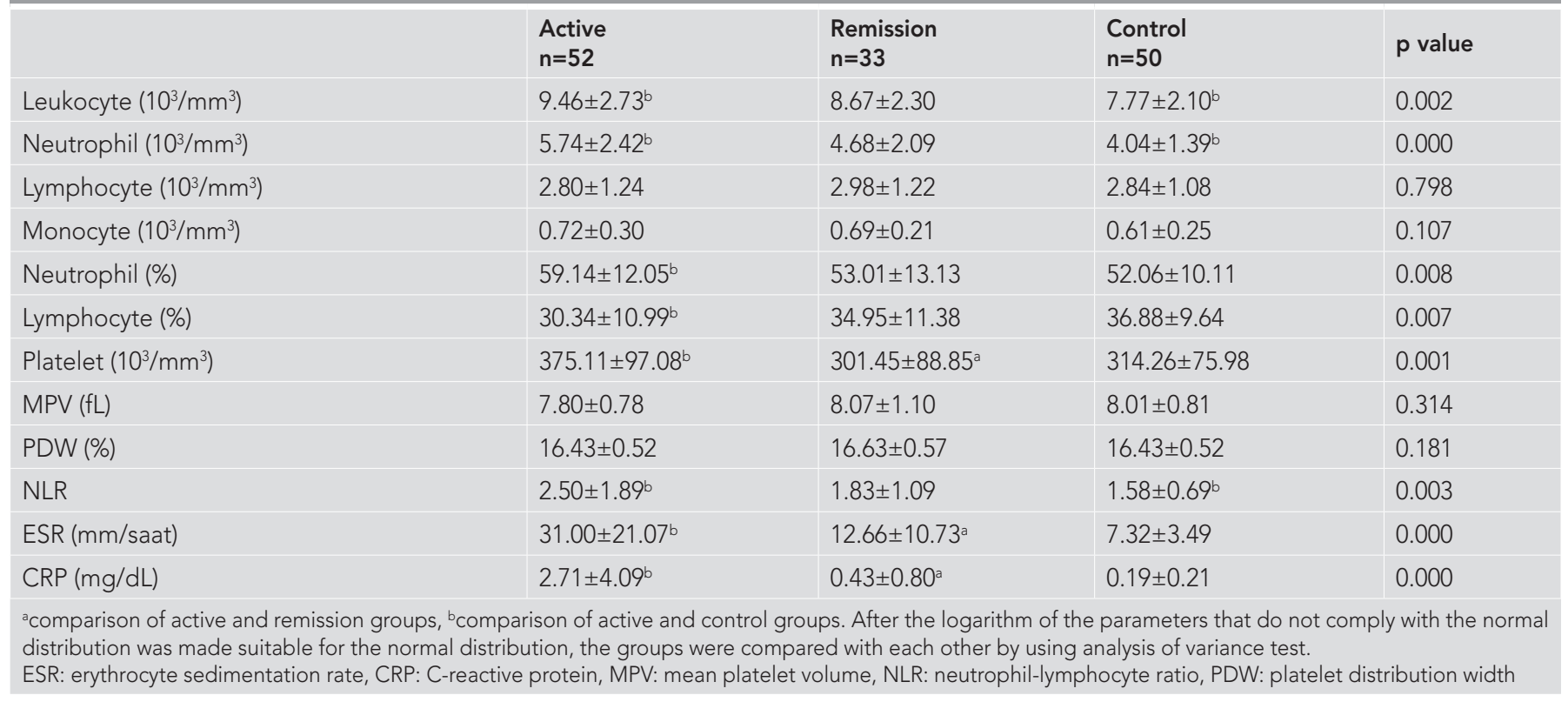

\begin{tabular}{|c|c|c|c|c|}
\hline & $\begin{array}{l}\text { Active } \\
n=52\end{array}$ & $\begin{array}{l}\text { Remission } \\
n=33\end{array}$ & $\begin{array}{l}\text { Control } \\
n=46\end{array}$ & $p$ value \\
\hline $\begin{array}{l}\text { Visfatin } \\
\text { (ng/dL) }\end{array}$ & $2.89 \pm 2.65^{b}$ & $2.10 \pm 1.81$ & $1.74 \pm 1.28^{b}$ & 0.021 \\
\hline $\begin{array}{l}\text { Adiponectin } \\
\text { (pg/dL) }\end{array}$ & $20.14 \pm 24.10$ & $8.48 \pm 6.25^{a}$ & $17.17 \pm 21.28$ & 0.046 \\
\hline
\end{tabular}

\section{DISCUSSION}

Although adipose tissue was initially thought to store only triglycerides and participate in thermogenesis, adipose tissue also acts as an active endocrine gland and secretes many bioactive peptides and hormones. Adipocytes generally affect both metabolism and immunity; the latter is mediated by various inflammatory and proinflammatory molecules derived from the adipose tissue (16).

Both the adaptive and innate immune system are primarily involved in the inflammatory process (17). Neutrophils are major components of the immune response against inflammation or infection, playing a key role in both the activation and migration of antigen-presenting cells. Neutrophil chemotaxis promotes the migration of monocytes to the inflammation site. They are also involved in monocyte differentiation into pro- or anti-inflammatory macrophages. Both reactive oxygen species and lytic enzymes that are released from the neutrophils lead to tissue injury $(18,19)$.

Adipokines that have proinflammatory properties did not directly participate in inflammation, but they are involved in the initiation and termination of the inflammation phase (20).
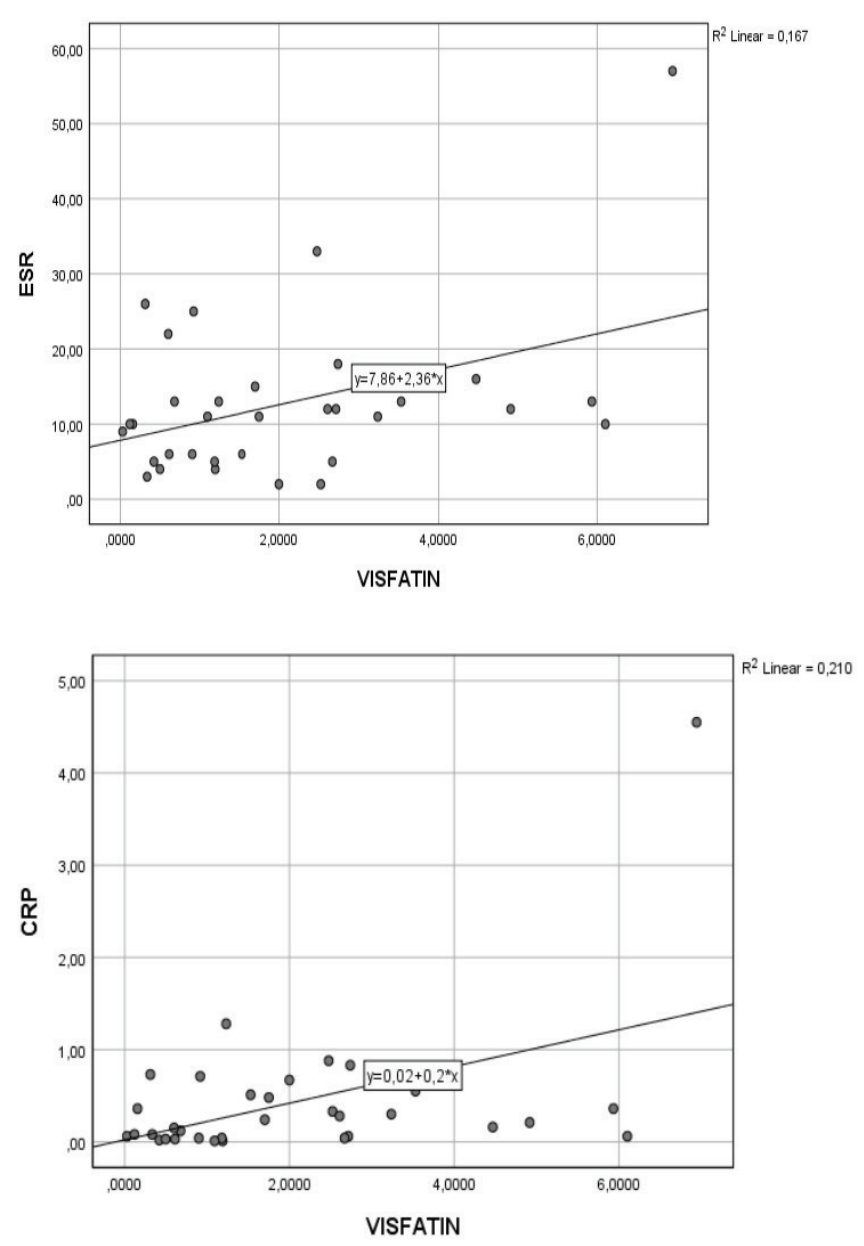

Figure 3. Relationship between visfatin and serum levels of $\mathrm{C}$-reactive protein and erythrocyte sedimentation rate ESR: erythrocyte sedimentation rate, CRP: C-reactive protein 
In our study, we investigated the possible relationship between adiponectin and visfatin with CBC parameters (mainly leukocytes, neutrophils, lymphocytes, monocytes and platelets), ESR and CRP that are considered routine biochemical parameters that manage the inflammatory process in JIA. Leukocyte [white blood cells (WBC)] counts are strikingly elevated in children with JIA. Since JIA is an inflammatory disease, significant difference was found in WBC values during the active and remission periods when compared with the control group. Conversely, Güneş et al. (21) reported no significant difference in WBC between the active and remission periods, whereas Punzi et al. (22) reported higher WBC levels in patients with JIA than in those without JIA, which is similar to the results of the present study. Furthermore, neutrophil counts were higher in both active and remission groups than in the control group. Possible reason is that neutrophils are activated by TNF- $\alpha$, a cytokine that is involved in both tissue damage and repair process. We can assume that neutrophils activate the macrophagebased immune response, and this may trigger the conversion of proinflammatory process into anti-inflammatory and proliferative processes in damaged tissues. This assumption may explain the high neutrophil counts in both active and remission periods (23).

Although lymphocytes are not part of adipose tissues, there is a physical proximity between the lymph nodes and pericapsular adipose tissue surrounding them. Thus, a probable paracrine effect may be observed between adipocytes and lymphocytes $(24,25)$. Directing the lymphocyte transport through the lymph nodes to the spleen is mutually controlled by the regulation of the neutrophil production rate during haematopoiesis. Apoptotic neutrophils on the area of tissue destruction are phagocytised by the migration of macrophages to the region by chemotaxic agents derived from neutrophils $(21,26)$. Therefore, while the neutrophil counts increase in the active period, the NLR subsequently shifts in favour of the lymphocytes in the remission period. Based on this data, in our study, NLR was also evaluated in patients with JIA. NLR was significantly higher in the active group than in the control group, with elevated neutrophil counts related to disease activity. However, this ratio decreased in the remission period. NLR is an acceptable inflammation marker, and it may be useful in the management of disease activity. A recent study by Güneş et al. (21) reported significantly high NLR in both active and inactive (remission subjects) groups in comparison with that in the control group, although no significant difference was found in NLR between the active and remission groups. Although NLR may not be useful in distinguishing active and remission periods, it may be a reliable marker to evaluate disease activity at JIA onset.

Thus far, no reliable, sensitive and specific biochemical parameters have been established to define the diagnosis, prognosis and follow-up of JIA (27). ESR and CRP are used as routine clinical laboratory parameters in evaluating disease activity (28). ESR depends on the concentration of plasma fibrinogen and indirectly reflects the concentration of acute-phase proteins. The analysis of ESR demonstrates the disease activity both at onset and follow-up of patients with JIA. Similarly, CRP is an inflammatory parameter, i.e. an acute-phase protein (29). During active disease, high ESR and CRP values are related to immunologic response, particularly innate immune phase. In the present study, we demonstrated higher ESR and CRP values in the active group than in the control group, supported by similar results in the literature (30).

In vitro, activated platelets release proinflammatory cytokine IL-1 $\beta$. This cytokine plays a major role in vascular inflammation, taking place in the centre of the cytokine cascade. Activated platelets induce the release of IL-6 and IL-8 from the vascular smooth muscles through IL-1. In turn, IL-1 accelerates neutrophil adhesion to endothelial cells (31). Güneş et al. (32) reported high platelet counts in patients with active JIA compared with individuals without JIA. Ece et al. (33) showed that platelet counts decreased as a response towards therapy in the remission group. Our results also correlated with these recently published results. We found high platelet counts in both the active and remission groups when compared with control subjects. Furthermore, platelet counts positively correlated with the neutrophil counts and CRP.

In the present study, both adiponectin and visfatin levels were evaluated in patients with JIA during the active and remission periods. We demonstrated a significant decrease in visfatin levels in the control group when compared with that in the active group, indicating visfatin as a reliable parameter for the determination of disease activity, exhibiting a correlation between inflammatory parameters ESR and CRP. By contrast, a significant difference was observed in adiponectin levels between the active and remission groups. A marked decline was noted in adiponectin levels in the remission period compared with that in the control group, indicating that it may be useful in the management of the JIA treatment. In a study reported by Aranda-Valera et al. (34), alterations of adipokines function might be exhibited with chronic inflammation, even under remission conditions, and this inflammatory process might promote the anti-inflammatory response related with the adipose tissue in patients with JIA.

\section{Study Limitations}

This study has some limitations including the small sample size and unequal distribution in the subgroups.

\section{CONCLUSION}

The adipose tissue plays an essential role in the inflammatory process, particularly with adipokines. However, JIA is a common rheumatological problem in the paediatric population and considered an inflammatory disease accompanied with immune response disorder. The present study highlights the concentrations of both visfatin and adiponectin in JIA, and these two adipose tissue-derived biochemical parameters may play a role in the management of disease activity and monitoring of treatment. Moreover, this study emphasised that NLR, a very simple and useful test to predict anti-inflammatory response, may be a reliable marker of disease activity. Further studies with a large sample size and detailed characterisation of subgroups are warranted to validate the role of adiponectin and visfatin in the evaluation of 
disease activity. This will provide appropriate management strategy of the disease and improve the quality of life in patients with JIA.

Ethics Committee Approval: The study protocol was approved by Ethics Committee of İstanbul University-Cerrahpaşa, Cerrahpaşa Faculty of Medicine (approval number: 02-107694, approval date: 07.04.2015).

Informed Consent: A written informed consent was obtained from all patients.

Peer-review: Externally and internally peer-reviewed.

Author Contributions: Surgical and Medical Practices - K.B., A.A.Y., S.Ş., Ş.D., Ö.K.; Concept - O.Ç., H.E., Z.B.G., K.B., A.A.Y., S.Ş., Ö.K.; Design - O.Ç., Ö.B.E., K.B., A.A.Y., S.Ş., Ö.K., M.K.; Data Collection and/ or Processing - O.Ç., Ö.B.E., H.E., Z.B.G., K.B., Ş.D.; Analysis and/or Interpretation - O.Ç., Ö.B.E., Z.B.G., K.B., Ş.D., M.K.; Literature Search O.Ç., Ş.D., M.K.; Writing - O.Ç., Ş.D., M.K.

Conflict of Interest: The authors have no conflict of interest to declare.

Financial Disclosure: The present work was supported by the Research Fund of İstanbul University-Cerrahpaşa. (Project no: 20479).

Etik Komite Onayı: Çalışma protokolü İstanbul Üniversitesi-Cerrahpaşa Cerrahpaşa Tıp Fakültesi Etik Kurulu tarafından onaylandı (onay no: 02 107694, onay tarihi: 07.04.2015).

Hasta Onamı: Tüm hastalardan yazılı bilgilendirilmiş onam alındı.

Hakem Değerlendirmesi: Editörler kurulu ve editörler kurulu dışında olan kişiler tarafından değerlendirilmiştir.

Yazar Katkıları: Cerrahi ve Medikal Uygulama - K.B., A.A.Y., S.Ş., S..D., Ö.K.; Konsept - O.Ç., H.E., Z.B.G., K.B., A.A.Y., S.Ş., Ö.K.; Dizayn - O.Ç., Ö.B.E., K.B., A.A.Y., S.Ş., Ö.K., M.K.; Veri Toplama veya İşleme - O.Ç., Ö.B.E., H.E., Z.B.G., K.B., Ş.D.; Analiz veya Yorumlama - O.Ç., Ö.B.E., Z.B.G., K.B., Ş.D., M.K.; Literatür Arama - O.Ç., Ş.D., M.K.; Yazan - O.Ç., S..D., M.K.

Çıkar Çatışması: Yazarlar tarafından çıkar çatışması bildirilmemiştir.

Finansal Destek: Bu çalışma, İstanbul Üniversitesi-Cerrahpaşa Araştırma Fonu tarafından desteklenmiștir. (Proje no: 20479).

\section{REFERENCES}

1. Barut K, Adrovic A, Şahin S, Kasapçopur Ö. Juvenile idiopathic arthritis. Balkan Med J 2017; 34: 90-101.

2. Wallace CA, Huang B, Bandeira M, Ravelli A, Giannini EH. Patterns of clinical remission in select categories of juvenile idiopathic arthritis. Arthritis Rheum 2005; 52: 3554-62.

3. Kessel C, Holzinger D, Foell D. Phagocyte-derived S100 proteins in autoinflammation: putative role in pathogenesis and usefulness as biomarkers. Clin Immunol 2013; 147: 229-41.

4. Frizinsky S, Haj-Yahia S, Machnes Maayan D, Lifshitz Y, Maoz-Segal R, Offengenden I, et al. The innate immune perspective of autoimmune and autoinflammatory conditions. Rheumatology (Oxford) 2019; 58(Suppl 6): vi1-8.

5. Shoop-Worrall SJW, Kearsley-Fleet L, Thomson W, Verstappen SMM, Hyrich KL. How common is remission in juvenile idiopathic arthritis: a systematic review. Semin Arthritis Rheum 2017; 47: 331-7.

6. Naz S, Aslam R, Ullah E, Shahzad F, Mushtaq A, Ahmad TM, et al. Association of erythrocyte sedimentation rate and c-reactive proteins with active disease in Juvenile Rheumatoid Arthritis. Pak Pediatr J 2014; 38: 24-30.

7. Żółkiewicz J, Stochmal A, Rudnicka L. The role of adipokines in systemic sclerosis: a missing link? Arch Dermatol Res 2019; 311: 251-63.

8. Landecho MF, Tuero C, Valentí V, Bilbao I, de la Higuera M, Frühbeck G. Relevance of leptin and other adipokines in obesity-associated cardiovascular risk. Nutrients 2019; 11: 2664.

9. Fatel ECS, Rosa FT, Simão ANC, Dichi I. Adipokines in rheumatoid arthritis. Adv Rheumatol 2018; 58: 25.

10. Scotece M, Conde J, López V, Lago F, Pino J, Gómez-Reino JJ, et al. Adiponectin and leptin: new targets in inflammation. Basic Clin Pharmacol Toxicol 2014; 114: 97-102.

11. Abella V, Scotece M, Conde J, López V, Lazzaro V, Pino J, et al. Adipokines, metabolic syndrome and rheumatic diseases. J Immunol Res 2014; 2014 : 343746. doi: 10.1155/2014/343746.
12. Moschen AR, Kaser A, Enrich B, Mosheimer B, Theurl M, Niederegger $H$, et al. Visfatin, an adipocytokine with proinflammatory and immunomodulating properties. J Immunol 2007; 178: 1748-58.

13. Kim SR, Bae YH, Bae SK, Choi KS, Yoon KH, Koo TH, et al. Visfatin enhances ICAM-1 and VCAM-1 expression through ROS-dependent NFKB activation in endothelial cells. Biochim Biophys Acta 2008; 1783: 886-95.

14. Petty RE, Southwood TR, Manners P, Baum J, Glass DN, Goldenberg J, et al. International League of Associations for Rheumatology. International League of Associations for Rheumatology classification of juvenile idiopathic arthritis: second revision, Edmonton, 2001. J Rheumatol 2004; 31: 390-2.

15. Wallace CA, Huang B, Bandeira M, Ravelli A, Giannini EH. Patterns of clinical remission in select categories of juvenile idiopathic arthritis. Arthritis Rheum 2005; 52: 3554-62.

16. Corrêa LH, Heyn GS, Magalhaes KG. The impact of the adipose organ plasticity on inflammation and cancer progression. Cells 2019; 8: 662

17. Fandiño Vargas MC. (June 3rd 2020). Innate immunity and autoimmune diseases [Online First], Intech Open 2020: June 3. doi: 10.5772/ intechopen.91366. (Online ahead of print)

18. Lawrence SM, Corriden R, Nizet V. How Neutrophils Meet Their End. Trends Immunol 2020; 41: 531-44.

19. de Oliveira S, Rosowski EE, Huttenlocher A. Neutrophil migration in infection and wound repair: going forward in reverse. Nat Rev Immunol 2016; 16: 378-91.

20. Mancuso P. The role of adipokines in chronic inflammation. Immunotargets Ther 2016;5:47-56.

21. Güneş A, Ece A, Şen V, Uluca Ü, Aktar F, Tan I, et al. Correlation of mean platelet volume, neutrophil-to-lymphocyte ratio, and disease activity in children with juvenile idiopathic arthritis. Int J Clin Exp Med 2015; 8: 11337-41.

22. Punzi L, Ramonda R, Glorioso S, Schiavon F, Mariuz S, Gambari PF. Predictive value of synovial fluid analysis in juvenile chronic arthritis. Ann Rheum Dis 1992; 51: 522-4.

23. Brown RA, Henderlight M, Do T, Yasin S, Grom AA, DeLay M, et al. Neutrophils from children with systemic juvenile Idiopathic arthritis exhibit persistent proinflammatory activation despite long-standing clinically inactive disease. Front Immunol 2018; 9: 2995.

24. Cousin B, Munoz O, Andre M, Fontanilles AM, Dani C, Cousin JL, et al. A role for preadipocytes as macrophage-like cells. FASEB J 1999; 13: 30512.

25. Robker RL, Collins RG, Beaudet AL, Mersmann HJ, Smith CW. Leukocyte migration in adipose tissue of mice null for ICAM-1 and Mac-1 adhesion receptors. Obes Res 2004; 12: 936-40.

26. Imtiaz F, Shafique K, Mirza SS, Ayoob Z, Vart P, Rao S. Neutrophil lymphocyte ratio as a measure of systemic inflammation in prevalent chronic diseases in Asian population. Int Arch Med 2012; 5: 2.

27. Akay Tekelı A, Oner A. Clınıcal and laboratory findıngs of chıldren with Identıfied ıdıopathıc arthritıs, ınvestıgatıon on treatment and prognosıs seven years experıence. Pediatr Dimensions 2017; 2: 1-7.

28. Bray C, Bell LN, Liang H, Haykal R, Kaiksow F, Mazza JJ, et al. Erythrocyte sedimentation rate and c-reactive protein measurements and their relevance in clinical medicine. WMJ 2016; 115: 317-21.

29. Sarkar S, Alam MM, Das G, Datta S. Inflammatory markers and disease activity in juvenile Idiopathic arthritis. Indian J Pediatr 2017; 84: 349-56.

30. Gorczyca D, Postępski J, Czajkowska A, Paściak M, Prescha A, Olesińska $E$, et al. The profile of polyunsaturated fatty acids in juvenile idiopathic arthritis and association with disease activity. Clin Rheumatol 2017; 36: 1269-79.

31. Thomas MR, Storey RF. The role of platelets in inflammation. Thromb Haemost 2015; 114: 449-58.

32. Güneş A, Ece A, Şen V, Uluca Ü, Aktar F, Tan I, et al. Correlation of mean platelet volume, neutrophil-to-lymphocyte ratio, and disease activity in children with juvenile idiopathic arthritis. Int J Clin Exp Med 2015; 8: 11337-41.

33. Ece A, Şen V, Yel S, Güneş A, Uluca Ü, Tan I, et al. Clinical and laboratory characteristics and follow up results of 121 children with juvenile Idiopathic arthritis. Eur J Gen Med 2015; 10: 136-41.

34. Aranda-Valera IC, Arias de la Rosa I, Roldán-Molina R, Ábalos-Aguilera MDC, Torres-Granados C, Patiño-Trives A, et al. Subclinical cardiovascular risk signs in adults with juvenile idiopathic arthritis in sustained remission. Pediatr Rheumatol Online J 2020; 18: 59. 